\title{
An Exploratory Study on Technological Innovation of Agricultural Science and Technology Enterprises in China
}

\author{
Qiong Yao, Meisi Xu, Wenfang Jiang, Yong Zhang \\ Management School, Jinan University, Guangzhou, China \\ Email: yaoqiong@126.com
}

Received 12 June 2014; revised 13 July 2014; accepted 14 August 2014

Copyright (C) 2014 by authors and Scientific Research Publishing Inc.

This work is licensed under the Creative Commons Attribution International License (CC BY). http://creativecommons.org/licenses/by/4.0/

c) (i) Open Access

\begin{abstract}
Technological innovation of agricultural science and technology (AST) of enterprises plays an important role in the development of high-tech agriculture. Enhancing technological innovation capability is the key for Agricultural Science and Technology (AST) enterprises to develop sustainably. This study examines the main dimensions and characteristics of the AST enterprises' technological innovation. In-depth interview method is employed in this paper. The finding points out that R\&D capability and marketing capability are two important capabilities of technological innovation. And the characteristics of R\&D and marketing of AST enterprises are summarized. Finally, the article discusses the conclusions and implications of the study.
\end{abstract}

\section{Keywords}

Agricultural Science and Technology Enterprises, Technological Innovation, R\&D Capability, Marketing Capability

\section{Introduction}

How to improve the capability of technological innovation has become a hot topic among many scholars. Technological innovation plays a crucial role in enhancing the competitiveness and performance of AST enterprises [1]. However, there are some outstanding contradictions in China, such as the paradox between powerful innovation sources (science and technology) and weak technological innovation capability of enterprises [2]. Meanwhile, technological innovation of AST enterprises in China has some characteristics, for instance, small scale, insignificant difference of products and low scientific contents [3]. In order to know more about AST enterprises' technological innovation capability, we must explore in depth according to Chinese context as well as the objec- 
tive law of agricultural technology innovation. It is urgent to realize the main dimensions of AST enterprises' technological innovation.

In this study, AST enterprises' technological innovation is a process that enterprises develop and produce new products or offer new services to realize the commercialization and achieve new market value-added. In the progress they apply innovation knowledge, new technique, and use new mode of production [4] [5]. In this process, what are the main dimensions of technological innovation? What is the characteristic of technological innovation? This study explores deeply into AST enterprises' technological innovation in micro perspective, analyzes the characteristic of AST enterprises and provides practical guiding which is of significance to AST enterprises.

The article is organized as follows. It starts with a review of the literature on these topics. Next, it explains the investigation method adopted, followed by the analysis and discussion of the findings. In the last section, it describes implications for managers and public policy makers.

\section{Literature Review}

R\&D capability and marketing capability are the key contents of AST enterprises' technological innovation. Technological innovation is a chain of links: market needs-conception-R\&D-pilot (demonstration)-manufacturing-marketing, and involves the R\&D, production and marketing departments [6]-[9]. Technological capability refers to organizational skills and abilities that enable firms to employ various technologies and integrate with other complementary resources to supply the differentiated products and services [10]-[13]. And Empirical evidence shows that technological capability leads to superior firm performance [12] [14] [15]. On the basic of the combination of interdisciplinary theories, a growing number of scholars refine technological innovation capability in multiple dimensions [1] [16] [17], such as R\&D capability, production capability, and marketing capability. They further study influence of different capabilities on performance [18] [19]. As for the AST enterprises, it is well known that R\&D capability is the core of technological innovation. In spite of the advantage of technological resources, a part of enterprises are lack of market advantage. To transform a technological advantage into a market advantage, AST enterprises should strengthen market innovation and improve marketing capability [20] [21]. In addition, R\&D and marketing capabilities are also the key point of combination of technological innovation theory and marketing theory. In the technological innovation theory, technological innovation stresses new products and market profit, which is a marketing and technological activity [8]. In the marketing theory, the R\&D capability of an enterprise is its capacity to develop or apply the technologies to produce new and effective products and services [15]. Marketing capability is what an enterprise can understand and predict better than the competitors and deliver their products and service to the customers [22] [23]. The former creates the value to meet customers' needs for products and services; the latter delivers its value through marketing mix. They affect each other in some aspects [24] [25], and have synergistic effects, which enable the enterprises to develop new products to respond to customers' needs and significantly influences firms' marketplace performance more than they do individually [18] [26] [27].

AST enterprises' R\&D and marketing is specific. The particularity of agriculture discriminates AST enterprises' technological innovation from other high-tech enterprises in many aspects [5] [28]. For example, in R\&D, AST enterprises' technological innovation is characterized by a long cycle of research and development, strong regional features and publicity. In marketing, due to a contradiction between advanced technological innovation and the insufficiency of famers' ability, enterprises need to adopt the mode of demonstration and popularization to promote new products (new techniques).

Although scholars illustrated the importance of R\&D and marketing of AST enterprises, the theoretical basis is relatively weak, and empirical research is rare. Moreover, scholars pointed out some AST enterprises' characteristics in R\&D and marketing, but haven't explored the concrete embodiment and the cause.

Based on the related research, this study provides a comprehensive analysis of technological innovation with the national and industrial characteristics. It explores AST enterprises' technological innovation in view of R\&D and marketing. We hope the implications of the study are beneficial to the development of AST enterprises in China.

\section{Methodology}

As insufficient theoretical support for AST enterprises' technological innovation, this study uses in-depth inter- 
view method to conduct an exploratory research. The remarkable characteristic of in-depth interview is deep and meticulous. With this method, we can get more vivid qualitative material from the enterprises' managers, through one-to-one interviews. Based on subjective and insightful analysis, results are summarized.

The data collection process is shown as follows: firstly interviewees are asked to review the specific operation and encountered problems of R\&D or marketing department. Then they are required to detail R\&D and marketing of their enterprises. Finally, they are asked to make a summary of their narrative, which will be used in confirmatory procedure to verify the appropriateness of the interviewees' subjective interpretation.

The interviewees were managers who were deeply familiar with the R\&D and marketing departments; they have engaged in this industry for a long time, and always have a systematic think. Therefore, the interviewees could be expected to hold a position that makes him or her more knowledgeable about the issues being researched, and then we can get more real and consistent information.

13 managers were selected as interviewees. We conducted a face-to-face interview or a telephone interview. The interviews lasted at least half an hour. And all the conversations were recorded. Before every interview, we gave a five-minute talk to the interviewees about research purposes and topics. It is beneficial for interviewees to review all the relative information. In interviews, according to the interview outline, some open questions were applied, for example, "how to develop R\&D or marketing in your enterprise?” This form of unstructured, direct, and personal method is particularly helpful for gleaning the interviewees' perceptions. After the interviews, interviewees' views were repeated by the interviewers. For unclear points, some supplements and explanations were made, so as to confirm the data reliability.

Recorded data were transcribed verbatim for content analysis, which were read and analyzed repeatedly. In order to obtain a deep understanding, the text was interpreted from different perspectives. And we tried to enrich the existing theory with the research results.

We focused on the main dimensions and the characteristic of AST enterprises' technological innovation and concluded the information provided by interviews. We find that R\&D capability and marketing capability are two important aspects of AST enterprises' technological innovation. And the R\&D capability and marketing capability have some characteristics.

\section{AST Enterprises' Technological Innovation and R\&D/Marketing}

As we all know, technological innovation is the way to improve enterprises' performance, and it is the same to AST enterprises. From the interviewees' text, it indicates that R\&D and marketing are two important aspects of technological innovation. All the interviewees referred to the significance of R\&D and marketing, and they discussed the significance from different perspectives.

\section{1) Technological innovation levels}

According to technological innovation level, AST enterprises present three levels: high, medium and low. The role of R\&D and marketing are different in different kinds of enterprises.

Leading AST enterprises play important roles through researching industry's hotspot and introducing some new ideas. For instance, they research how to irrigate more farmland, and improve the original irrigation technology or even redesign it. Also, they would consider how to make the crop yield increase. By adopting the hybridization technology, the R\&D personnel do a lot of experiments to create new products. In order to attract consumers, they need to change the appearances of the products, etc. Therefore, through $R \& D$, the leader enterprises can cater to the market and then occupy the high-end market. However, for the low-end enterprises, they usually increase sales and realize scale production by means of promotion. For instance, they may choose local TV stations to promote products and offer gifts such as some articles, detergent etc to attract farmers. But for the medium-end enterprises, they always do not have a clear direction, which result in the market followers. (Interviewee 1)

\section{2) Different parts of industry chain}

From the perspective of industry chain, the interviewees elaborate the role of R\&D and marketing capability in upstream, middle stream and downstream enterprises. The results show that R\&D is important for the upstream and middle stream enterprises. The upstream enterprises focus on the research and development of new products. The middle stream enterprises pay more attention to production. And the main task for the downstream enterprises is marketing.

The primary task of the upstream AST enterprises is R\&D. Taking seedling and feeding industry for example, 
these products have higher requirement for technology that they must be researched by long-term and repeated experiments before being launched. Therefore, enterprises must develop new products, which indicate that R\&D departments are particularly important. The AST enterprises that are in the middle reaches mainly focus on the process of production. So they need more advanced technology to monitor production process to ensure efficient run of supply chains. In planting and breeding industry, enterprises need to develop more advanced technology by many iterative tests, controlling volume and timing of fertilizer, pesticides. The downstream AST enterprises' customers are generally farmers. They often let these farmers get together and then explain agricultural knowledge and play the promotional video about new products and its usage to the farmers. Also, sending these products to the influential farmers for free would influence more and more people to purchase. Thus, the enterprises must put a great amount of resources in marketing department to get a bigger market share. (Interviewee 2)

\section{3) Two kinds of China AST enterprises}

China AST enterprises can be divided into two kinds: one is transformed from scientific research institutions; the other is independent private enterprises. The conversion AST enterprises realize technological innovation by $\mathrm{R} \& \mathrm{D}$, and the private AST enterprises realize it by marketing.

AST enterprises, transformed from scientific research institutions, keep some characteristics of scientific research institutions. For example, they usually have strong scientific research strength and more scientific achievements, which laid a good foundation for the development of the enterprises. These enterprises attach great importance to R\&D and invest a great deal of manpower and money. But their marketing is so weak, maybe only set up a sales department. The ratio of staffs in R\&D section to the whole employees is almost $60 \%$. $\mathrm{R} \& \mathrm{D}$ is very important to technological innovation. And they began to strengthen marketing capability. R\&D, production and marketing departments are independent in private AST enterprises. They always improve their innovation through marketing capability. They invest most of manpower, material and financial resources in marketing. (Interviewee 3)

All these show that R\&D and marketing are two main aspects of AST enterprises' technological innovation. If enterprises want to increase technological innovation capability, R\&D and marketing capabilities are the key. And R\&D and marketing capability are interdependent and indispensable.

\section{The Characteristics of R\&D and Marketing in China AST Enterprises}

\subsection{R\&D in AST Enterprises}

R\&D in AST enterprises can generally be divided into basic research and applied research. Enterprises focusing on basic research have independent R\&D department and better R\&D capability. But the kind of AST enterprises is still not yet fully fledged. And in the enterprises focusing on applied research, most of the R\&D functions are carried out by technological departments.

The process of R\&D takes 2 - 3 years, if not 6 - 10 years. Because of the long cycle, most enterprises don't conduct research independently but other two innovation modes: united application (co-work with other organizations in carrying out technological innovations) and direct purchases (purchase scientific research achievements from colleges or scientific research institutions). The process of united application is: 1) analyze demands; 2) establish research projects; 3) co-work with other organizations; 4) declare achievements; 5) transfer the technological achievements; 6) evaluate products' safety; 7) put on into the market. The process of direct purchases is: 1) purchase technological achievements from colleges or scientific research institutions; 2) carry out laboratory study; 3 ) test in clinical trials; 4) submit to the approval organizations; 5) get a license. (Interviewee 4 and 5)

In R\&D, strategic plans and lots of resources are needed, which are basic guarantee for all kinds of activities. And project implementation and management is very important. We elaborate the characteristics of R\&D in R\&D strategy, R\&D investment, project implementation and management.

\section{1) $R \& D$ strategy}

Nowadays, most leaders of AST enterprises have gradually realized the importance of $R \& D$. R\&D departments have become more and more important, and R\&D projects are usually linked with enterprise management strategy. Some enterprises provide a reward to the staffs who contribute in product innovation and process innovation. On the contrary, some enterprises still have not established an independent R\&D department, and most functions are carried out by technological departments. What's more, the participation of other departments (es- 
pecially marketing departments) in R\&D is not enough, which makes the products cannot meet customers demand. (Interviewee 6 and 7)

\section{2) R\&D investment}

R\&D investment contains two dimensions: R\&D personnel and R\&D funds. At present, R\&D investment of China AST enterprises presents three levels. Small and medium enterprises lack R\&D investment. They are usually market followers. Most of their products are existed in the market, so less resource is needed to invest in R\&D. Some enterprises carry out multi-development strategy. Their main business is new agricultural product development, but also engaged in other business (such as real estate, stock, etc.). They often invest the profits that were obtained from other business into agricultural R\&D. R\&D investment usually equals to demand. Two kinds of these enterprises have abundant R\&D investment. Some are leading enterprises in the industry (such as Guangdong Haida Group). They own research institutions and sufficient R\&D personnel. Fixed proportion of sales revenue is put into R\&D every year. Others are the enterprises carrying out government investment projects, which usually cooperate with colleges or scientific research institutions. The R\&D funds are mainly from the government. (Interviewee 6, 8, and 9)

\section{3) Project implementation and management}

Before implementing the project, innovative enterprises usually have a clear R\&D goal. They develop new products based on customers' need. However, less innovative enterprises are used to following the leading enterprises. Therefore, it is difficult to set a clear R\&D goal. In project implementation, R\&D personnel must consider the effect of crop's growing cycle and climate condition, and carry on experiment repeatedly. Due to long R\&D cycle and many undefined factors, enterprises try to control the whole process. Aiming at this goal, enterprises make a perfect research plan, ask R\&D personnel to report project status monthly and quarterly, and make some assessment and adjustment. What's more, R\&D personnel should communicate with production department and marketing department, in order to understand and predict better, and deliver their products and service to the customers. (Interviewee 2 and 6)

R\&D strategy, R\&D investment, Project implementation and management constitute AST enterprises’ R\&D. R\&D strategy is becoming more and more important, but the participation of other departments is still not enough. Most enterprises invest insufficiently in R\&D. In project implementation and management, the enterprises may draw up effective management strategy. The communication between $R \& D$ and other departments should be enhanced.

\subsection{Marketing in AST Enterprises}

Most China AST enterprises copy or duplicate the innovations. Too many substitutes are in the market. Establishing sales department is the only marketing activities. Marketing concept has not common been practiced. There is only a simple process of marketing: identify customers -design marketing projects-(select dealers)launch the new products to the market.

Marketing planning is the core of marketing. It reflects the status of marketing and provides guidance for the development of marketing [29]. Dealers play a role in linking customers and enterprises. Sales people who face customers directly are very important in marketing. What's more, many kinds of ways can be adopted to propagandize, in order to make customers know the new products more. We illustrate the characteristics of marketing in marketing planning, new product development, channel management, marketing communication and selling.

1) Marketing planning

Marketing planning can help enterprises to integrate market information and customers' needs into resource deployments, and to adjust the plans according to marketing performance. Some China AST enterprises just have a simple planning, which only contains predicted numbers of sales revenue and profit. And some enterprises make simple segmentation and formulate corresponding marketing strategy for each segment market. Such as the poultry breeding, chickens are raised with different feeding manners, which lead to different levels of maturity, and they will be put on different markets. (Interviewee 8 and 10)

\section{2) New product development}

It can effectively develop new product offerings to meet customers' needs. As the AST enterprises are still in the primary stage in China, copy or duplicate the innovations. Too many substitutes are in the market. Thus, the new products are generally less innovative and easy to be imitated. (Interviewee 2 and 11)

\section{3) Channel management}


It can help enterprises to build and sustain good channel relationships. The industrial market of AST enterprises is different from the consumer market. The behavior of distributors can affect the brand image of enterprises and the customers' willingness to buy. Most small AST enterprises adopt selling directly, mainly because they lack of money and have no capability to train dealers. Most enterprises sell through distribution channels. In this case, enterprises need enhance channel management. First of all, the enterprises prefer to select the experienced dealers Secondly, enterprises need to give some training and technical service to dealers, through promotional activities and seminars to popularize new products. What's more, enterprises will use different strategies to manage dealers. For the longtime collaborators, who approve of their corporate philosophy and products, enterprises will visit them regularly and give them some discounts. For new and inexperienced dealers, enterprises tend to give them a free trial of new products. Furthermore, some large enterprises have realized the importance of the network, and began to sell products on internet. Taking BangShiFu as an example, it established a website to display its products. Customers can communicate with them online and purchase directly. (Interviewee 7, 8, 12 and 13)

\section{4) Marketing communication}

It helps AST enterprises to affect the customer perceived value by the advertising, promotion and public relationship etc. Advertising and public relations are to provide and spread the related information that can increase mutual understanding and trust, and sales promotion is to enhance the short-term sales. Due to the target customers of the new products are farmers, the advertising is better to be simple and direct, for example, using simple packages, hanging banners on streets and vehicles, and attending annual exhibitions (such as animal husbandry exhibitions, food exhibitions and feedstuff exhibition, etc.). Another special communication method is oral marketing. That is, Enterprises will find more effective farmers, such as village cadres, large-scale breeding farmers, and then offer a trial for them, in order to win a good reputation. (Interviewee 4, 6, 7, 8 and 13)

\section{5) Selling}

There are some problems of AST enterprises sales people: lack of educational background, work with slackness, poor practice ability and high personnel liquidity. Generally, enterprises will provide training for sales people, includes sales skills training, professional knowledge training (concentrated in the new product usage) and social skills training (such as business etiquette and communication skills). And enterprises set an award or give bonus to the top sales. What's more, enterprises will implement some surveillance methods to manage sales people. (Interviewee 4, 6, 7, 8 and 13)

In general, AST enterprises only make simple marketing plan. Their new products are not innovative enough. Most AST enterprises sell products through dealers, so channel management is important. Marketing communication with customers should be innovative and frequent. Enterprises usually take effective measures to manage the sales people.

\section{Conclusions and Implications}

AST enterprises' technological innovation is explored systematically with in-depth interview method in this paper. The results show that R\&D and marketing are important in AST enterprises. To enhance enterprise's technological innovation, R\&D and marketing capability is the key [29] [30]. Many scholars study the relationship between technological innovation and business performance, and regard R\&D investment as the key point of technological innovation [31]. In this study, it finds that marketing is also the core of the technological innovation. What's more, we illustrate the characteristics of R\&D in R\&D strategy, R\&D investment, project implementation and management, while specify the marketing characteristics in marketing planning, new product development, channel management, marketing communication and selling. AST enterprises technological innovation is analyzed from these aspects, which enriches the literature of technological innovation.

The study enriches the existing literature of AST enterprises' technological innovation. What's more, some implications can be summarized as follows:

Firstly, the government should supply more financial support to China AST enterprises. Because of long R\&D cycle and complicated industrialization of R\&D achievements, enterprises prefer to invest in stocks, futures and real estate, which can gain high return in a short time, rather than invest in R\&D. In recent years, the government has formulated preferential policy to support AST enterprises. However, there are still some problems that hinder the implementation of the policy, such as the complex procedures and long period of time. Therefore, the government should supply more financial support to AST enterprises so that the enterprises can reduce the in- 
vestment risk and develop more innovative products.

Secondly, enterprises should improve technological innovation ability, pay attention to product differentiation, and promote brand image. There are so many competitors in agricultural market because of the low market entry. Most products have no clear difference, so it is difficult for enterprises to establish the brand that are likely to develop consumers' affection and faithfulness. Technological innovation ability and unique products are needed to create a brand image and attract customers' attention. For example, "number one organic pork" distinguishes itself from those swine that fed with artificial diet. It shapes a good brand image as innovative products. Its sales revenue increases from 30 million to 400 million.

Thirdly, enterprises should strengthen communication and collaboration between R\&D and marketing departments. The success of new products requires technical support and products for market need. Marketing department provides customers and market information. R\&D department deploys resources to research and develop new products which have a competitive advantage. Information sharing and a high degree of trust help enterprises make a better strategic decision.

In a word, the government's support and the communication between $\mathrm{R} \& \mathrm{D}$ and marketing departments are helpful for technological innovation. The capability of technological innovation lays a foundation for the enterprises' long-term development. With that, China AST enterprises will have a foothold in global market and a better development.

\section{Acknowledgements}

This study was carried out with financial support from the National Natural Science Foundation of China (71003043).

\section{References}

[1] Gao, Q.J. and Zhang, C.H. (2011) Analysis of Innovation Capability of 125 Agricultural High-Tech Enterprises in China. Innovation: Management, Policy and Practice, 13, 278-290. http://dx.doi.org/10.5172/impp.2011.13.3.278

[2] Huang, G., Li, Y., Liu, X.G. and Long, H.R. (2009) The Protruding Contradictions and Route Choices in Front of Chinese Agricultural Technology Innovations during the Transformation Stage. Soft Science, 10, 65-68.

[3] Zhang, L.X. (2007) Innovation Platform: The Research on the Status and Tactics of Independent Innovation of Agribusiness-The Consideration from the Investigation Program of "Qian, Bai, Shi” about the Innovation of Agribusiness. China Soft Science, 4, 127-133.

[4] Zhu, W.H. (2007) The Analysis of Agricultural Enterprise’s Technological Innovation Capability. Agricultural Economy, 6, 46-48.

[5] Van der Veen, M. (2010) Agricultural Innovation: Invention and Adoption or Change and Adaptation? World Archaeology, 42, 1-12. http://dx.doi.org/10.1080/00438240903429649

[6] Kotler, P. (1965) Competitive Strategies for New Product Marketing over the Life Cycle. Management Science, 12, 104-119. http://dx.doi.org/10.1287/mnsc.12.4.B104

[7] Yam, R.C., Guanb, J.C., Punc, K.F. and Tang, E.P. (2004) An Audit of Technological Innovation Capabilities in Chinese Firms: Some Empirical Findings in Beijing, China. Research Policy, 33, 1123-1140. http://dx.doi.org/10.1016/j.respol.2004.05.004

[8] Yang, P.P., Liu, Y. and Hou, J.G. (2009) The Analysis of the Degree of the Influence from Factors That Promote the New Product Development-Technological Innovativeness as a Moderator. Scientific Management Research, 7, 13-16.

[9] Zhu, D.Y. and Song, H.M. (1996) Studies on Technological Innovation Concept Analysis and Performance Evaluation. Soft Science, 6, 55-57.

[10] Moorman, C. and Slotegraaf, R.J. (1999) The Contingency Value of Complementary Capabilities in Product Development. Journal of Marketing Research, 36, 239-257. http://dx.doi.org/10.2307/3152096

[11] Omar, R., Takim, R. and Nawawi, A.H. (2012) Measuring of Technological Capabilities in Technology Transfer (TT) Projects. Asian Social Science, 8, 211-221.

[12] Song, M., Cornelia, D., Sangphet, H. and Calantone, R. (2005) Marketing and Technology Resource Complementarity: An Analysis of Their Interaction Effect in Two Environmental Contexts. Strategic Management Journal, 26, 259-276. http://dx.doi.org/10.1002/smj.450

[13] Zhou, K.Z. and Wu, F. (2010) Technological Capability, Strategic Flexibility, and Product Innovation. Strategic Management Journal, 31, 547-561. 
[14] Ju, M., Zhou, K.Z., Gao, G.Y. and Lu, J.Y. (2013) Technological Capability Growth and Performance Outcome: Foreign Versus Local Firms in China. Journal of International Marketing, 21, 1-16. http://dx.doi.org/10.1509/jim.12.0171

[15] Krasnikov, A. and Jayachandran, S. (2008) The Relative Impact of Marketing, Research-and-Development, and Operations Capabilities on Firm Performance. Journal of Marketing, 72, 1-11. http://dx.doi.org/10.1509/jmkg.72.4.1

[16] Razali, N.F., Suradi, N.R.M., Shahabuddin, F.A.A., Smail, W.R., Abidin, N.Z., Ahmad, N.A. and Mustafa, Z. (2012) Technological Innovation Capability in Malaysian-Owned Resource-Based Manufacturing Companies: Early Findings. AIP Conference Proceedings, 1522, 1483-1491.

[17] Zawislak, P.A., Alves, A.C., Gamarra, J.T., Barbieux, D. and Reichert, F.M. (2012) Innovation Capability: From Technology Development to Transaction Capability. Journal of Technology Management and Innovation, 7, 14-27. http://dx.doi.org/10.4067/S0718-27242012000200002

[18] Su, Z.F., Peng, J.S., Shen, H. and Xiao, T. (2013) Technological Capability, Marketing Capability, and Firm Performance in Turbulent Conditions. Management and Organization Review, 9, 115-137. http://dx.doi.org/10.1111/j.1740-8784.2011.00280.x

[19] Zhou, K.Z., Yim, C.K. and Tse, D.K. (2005) The Effects of Strategic Orientations on Technology- and Market-Based Breakthrough Innovations. Journal of Marketing, 69, 42-60. http://dx.doi.org/10.1509/jmkg.69.2.42.60756

[20] Gray, A., Boehlje, M., Amanor-Boadu, V. and Fulton, J. (2004) Agricultural Innovation and New Ventures: Assessing the Commercial Potential. American Journal of Agricultural Economics, 86, 1322-1329. http://dx.doi.org/10.1111/j.0002-9092.2004.00684.x

[21] Xie, Z.F. (2001) Development of the Main Body of Technological Innovation in Agriculture Technology Companies. China Soft Science, 9, 88-91.

[22] Morgan, N.A., Katsikeas, C.S. and Vorhies, D.W. (2012) Export Marketing Strategy Implementation, Export Marketing Capability and Export Venture Performance. Journal of the Academy Marketing Science, 40, 271-289. http://dx.doi.org/10.1007/s11747-011-0275-0

[23] Fang, E., Palmatier, R.W. and Grewal, R. (2011) Effects of Customer and Innovation Asset Configuration Strategies on Firm Performance. Journal of Marketing Research, 48, 587-602. http://dx.doi.org/10.1509/jmkr.48.3.587

[24] Eng, T.Y. and Duygu, T.O. (2011) Exploring a Dynamic Framework of Innovative Capability: A Theoretical Integration of Technological and Marketing Capabilities. Technology Analysis and Strategic Management, 23, 1001-1013. http://dx.doi.org/10.1080/09537325.2011.616700

[25] Su, Z.F., Xie, E. and Peng, J.S. (2010) Impacts of Environmental Uncertainty and Firm's Capabilities on R\&D Investment: Evidence from China. Innovation: Management, Policy and Practice, 12, 269-282. http://dx.doi.org/10.5172/impp.12.3.269

[26] O’Cass, A. and Ngo, L.V. (2011) Winning through Innovation and Marketing: Lessons from Australia and Vietnam. Industrial Marketing Management, 40, 1319-1329. http://dx.doi.org/10.1016/j.indmarman.2011.10.004

[27] Sok, P. and O’Cass, A. (2011) Achieving Superior Innovation-Based Performance Outcomes in SMEs through Innovation Resource-Capability Complementarity. Industrial Marketing Management, 40, 1285-1293. http://dx.doi.org/10.1016/j.indmarman.2011.10.007

[28] Gao, Q.J. (2008) An Empirical Analysis on Technological Innovation Capability and Its Influencing Factor of Agricultural Science and Technology Enterprises. Chinese Rural Economy, 7, 32-38.

[29] Nath, P., Nachiappan, S. and Ramanathan, R. (2010) The Impact of Marketing Capability, Operations Capability and Diversification Strategy on Performance: A Resource-Based View. Industrial Marketing Management, 39, 317-329. http://dx.doi.org/10.1016/j.indmarman.2008.09.001

[30] Verhoef, P.C. and Leeflang, P.S.H. (2009) Understanding the Marketing Department's Influence within the Firm. Journal of Marketing, 73, 14-37. http://dx.doi.org/10.1509/jmkg.73.2.14

[31] Li, Q.Z., Bai, G., Yu, J.Y. and Li, Y.Q. (2011) An Empirical Analysis of the Relationship between Marketing Capability and Innovation. China Soft Science Magazine, 1, 135-141. 
Scientific Research Publishing (SCIRP) is one of the largest Open Access journal publishers. It is currently publishing more than 200 open access, online, peer-reviewed journals covering a wide range of academic disciplines. SCIRP serves the worldwide academic communities and contributes to the progress and application of science with its publication.

Other selected journals from SCIRP are listed as below. Submit your manuscript to us via either submit@scirp.org or Online Submission Portal.
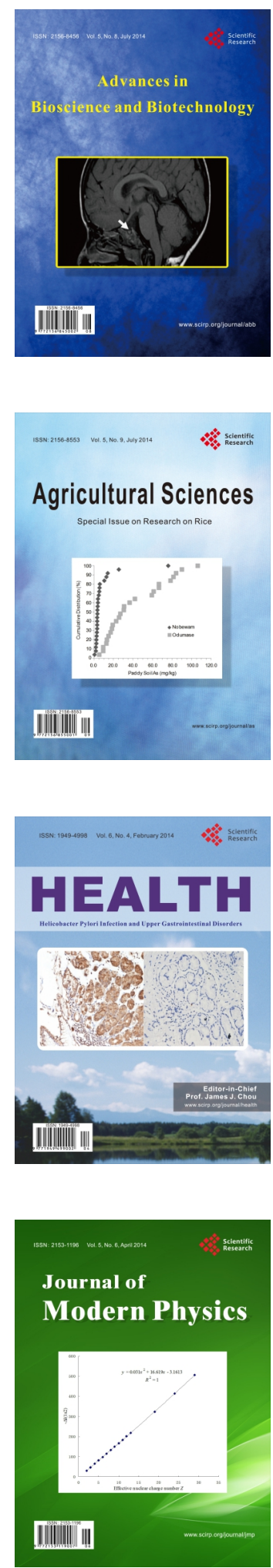
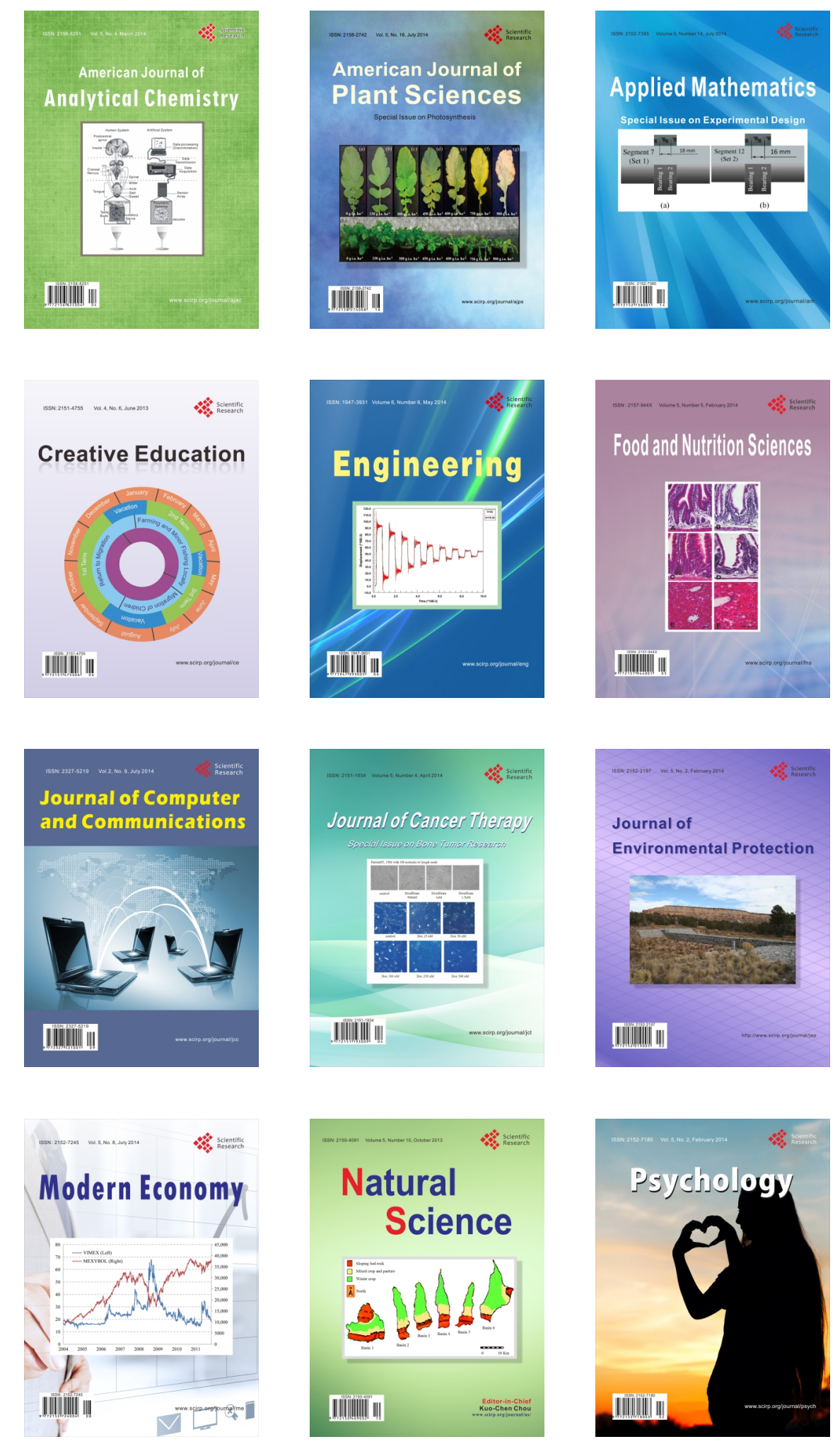